\title{
A study of students' perception about e-learning
}

\author{
Mehandi Vinayak Mahajan', Kalpana. $\mathbf{R}^{2, * *}$ \\ ${ }^{\mathbf{1}}$ Associate Professor, ${ }^{2}$ Professor and HOD, Dept. of Anatomy, Sri Muthukumaran Medical College, Hospital \& Research \\ Institute, Chennai, The Tamil Nadu Dr. M.G.R. Medical University, Guindy, Chennai, Tamil Nadu, India
}

\section{*Corresponding Author: Kalpana. $\mathbf{R}$}

Email: mm1710@gmail.com

Received: $8^{\text {th }}$ September, 2018

Accepted: $16^{\text {th }}$ October, 2018

\begin{abstract}
Introduction: e-learning is a relatively new phenomenon where currently the educators and students are grappling with the idea of its implementation and adaptation. With the speedy development of ICT and relative exposure of students to it, this study examines students' perceptions about e-learning which would help in a newer teaching learning experiences on the campus.

Materials and Methods: A quantitative approach with a structured questionnaire (18 close and 5 open ended) were used for data collection and it was presented to 150 respondents (2nd year M.B.BS) of age group 19-21yrs of different socioeconomic and demographic backgrounds.

Results and Discussion: 90\% students used internet daily. 78\% Male [M] and 92\% Female [F] respondents have an idea about elearning, while $92.5 \%$ of them indicated their interest to further guidance. $88 \% \mathrm{M}$ and $79 \mathrm{~F}$ students claim to not have any elearning facilities on campus. 58\% $\mathrm{M}$ and $49 \% \mathrm{~F}$ use various forms like emails, chat, blogs, video conferencing, WhatsApp to communicate with their faculties. $98 \%$ agree to find e-learning useful and $86 \% \mathrm{M}$ and $94 \% \mathrm{~F}$ are motivated to use it. $81 \% \mathrm{M}$ and $88 \% \mathrm{~F}$ find e-learning to be of interactive mode and $74 \% \mathrm{M}$ with $83 \% \mathrm{~F}$ agree about its cost effectivity. Implementing e-learning would improve performance in $99 \%$ students with $74 \% \mathrm{M}$ and $53 \% \mathrm{~F}$ indicating better understanding of the course. $75 \%$ believe that they will have ready access to e-learning courses while other don't due to lack of constant supply of internet. $38 \%$ agree elearning is disadvantages as it will replace faculties as they are comfortable with the traditional teaching style, while $26 \%$ disagree. 58\% $\mathrm{M}$ and $64 \% \mathrm{~F}$ think student will skip traditional classes while $39 \% \mathrm{M}$ and $35 \% \mathrm{~F}$ would be distracted. $86 \% \mathrm{M}$ and $92 \% \mathrm{~F}$ disagree with adapting difficulties on implementing newer e-learning modules and tools while the others agree due lack of training. Students gave suggestions to start blogs, online discussions, online submission of home work, and video assisted training for clinical work.

Conclusion: The study clearly depicts that e-learning has its benefits from a student's perspective and it will have a positive influence on their performance with better understanding of their courses. Thus for at least the following few years, the university needs come out with e-learning tools and modules for a better teaching -learning experience make a positive impact on the students career.
\end{abstract}

Keywords: Perception, e-learning.

\section{Introduction}

The electronic learning [e-learning] can be defined as a means of education that incorporates electronic equipments and tools and the interactivity that occurs between these and the people involved in the educational process (i.e.: instructors and learners). More and more E-Learning projects are being developed lately and some spectacular successes are recorded. ${ }^{1}$ With the hurried pace of technological and economic developments ${ }^{2}$ and its humongous penetration within the educational systems has lead to greater demands of making automated learning systems available to learners. Electronic learning (e-learning) is changing the way teaching and learning is taking place on university campuses. ${ }^{3}$ As e-learning is a relatively new phenomenon, currently both the educators and students are struggling with the idea of its implementation and adaptation respectively. In the our Institute, at present, traditional teaching is only followed, thus the main aim of the study was to understand the students perception towards this new concept of e-learning by determining their knowledge of e-learning along with the usage of technology, determining the usefulness as well as its benefits and challenges from student's view. Hence this study was needs assessment study to understand the perception about e-learning from students point. The results can thus be utilized to bring about the necessary changes by incorporating the newer techniques and tools into the students learning environments. This study would help in guiding the educators to take the necessary steps in incorporating these newer learning styles for the benefit of the learner as well as incorporating higher e-learning strategies, tools and technology at Institutional and university level.

\section{Materials and Methods}

The study was conducted in a Private Medical College in Chennai. IEC clearance was obtained. 150 $\mathrm{II}^{\text {nd }} \mathrm{yr}$ medical students $[\mathrm{n}=150$, Male $(\mathrm{M})=72$, Female $(F)=78$ ] of age group 19-21yrs, were participants and from different socioeconomic and demographic backgrounds. They had completed the 1st yr clinical postings and were mostly exposed to didactic forms of learning styles. They were briefed about the study and informed consent was taken. A semi structured 
validated feedback questionnaire (18 closed ended and 6 open ended sub-questions) focusing on the students perception about e-learning which was tested for internal validity, was given to them. The questionnaire was designed in three parts. Table 1 provides data about the students perception relating to use of internets and their knowledge about e-learning, Table 2 gives data about the benefits and Table 3 gives data about the challenges of e-learning from student's perception. The responses were collected from the students along with their suggestions. The data derived was tabulated and statistically analyzed using descriptive statistics.

\section{Results}

The following results were obtained:

Table 1: Student's usage of internet and knowledge of e-learning

\begin{tabular}{|c|c|c|c|c|c|c|}
\hline & $\begin{array}{c}\text { Males } \\
\%\end{array}$ & $\begin{array}{l}\text { No of } \\
\text { males }\end{array}$ & $\begin{array}{c}\text { Females } \\
\%\end{array}$ & $\begin{array}{l}\text { No of } \\
\text { female }\end{array}$ & $\begin{array}{c}\text { Total } \\
\%\end{array}$ & $\begin{array}{c}\text { Total } \\
\text { No=150 }\end{array}$ \\
\hline $\begin{array}{l}\text { 1. How often do you use the internet -At } \\
\text { least Once/Day }\end{array}$ & 94 & 68 & 86 & 68 & 90 & 136 \\
\hline - At least Once/Week & 6 & 4 & 12 & 10 & 9 & 14 \\
\hline - At least Once/month & 0 & 0 & 0 & 0 & 0 & 0 \\
\hline $\begin{array}{l}\text { 2. Do you have any idea about e- learning } \\
\text {-Yes }\end{array}$ & 78 & 56 & 92 & 72 & 85 & 128 \\
\hline No & 22 & 16 & 8 & 6 & 15 & 22 \\
\hline $\begin{array}{l}\text { 3. Are you interested in guidance on e- } \\
\text { learning- Yes }\end{array}$ & 90 & 65 & 95 & 74 & 92.5 & 139 \\
\hline No & 10 & 7 & 5 & 4 & 7.5 & 11 \\
\hline $\begin{array}{l}\text { 4. Does your Institute have a e-learning } \\
\text { facility - Yes }\end{array}$ & 13 & 9 & 21 & 16 & 17 & 25 \\
\hline If yes, in what form & \multicolumn{6}{|c|}{ Computer labs with internet, access to e-journals, educational sites } \\
\hline - No & 88 & 63 & 79 & 62 & 83.5 & 125 \\
\hline $\begin{array}{l}\text { 5. Do you use e-learning forms to } \\
\text { communicate with your faculties - Yes }\end{array}$ & 58 & 42 & 49 & 38 & 53.5 & 80 \\
\hline $\begin{array}{l}\text { If yes, what form of communication- } \\
\text { Email, Chats, Blogs, Face book, } \\
\text { WhatsApp, Instant Messaging Etc. }\end{array}$ & \multicolumn{6}{|c|}{$\begin{array}{l}42[23 \mathrm{M} \text { and } 19 \mathrm{~F}] \text { use Whats App, } 29[16 \mathrm{M} \text { and } 13 \mathrm{~F}] \text { use face book } \\
\text { and } 9[2 \mathrm{M} \text { and } 7 \mathrm{~F}] \text { use instant messaging. }\end{array}$} \\
\hline - No & 42 & 30 & 51 & 40 & 46.5 & 70 \\
\hline
\end{tabular}

Thus from Table 1, it is observed that $100 \%$ of students are internet users with $90 \%$ using it at least once a day. $85 \%$ [128] students were aware about it, $92.5 \%$ [139] wanted further guidance on e-learning with $7.5 \%$ [11] showing reluctance to embrace the newer technology. $83.5 \%$ [125] claim that there are no e-learning facilities on campus, while $17 \%$ [25] responded that the Institute has one. 53.5\% [80] do ecommunicate with faculties by WhatsApp, Facebook and instant messaging, but $47 \%$ do not do so.

Table 2: Student's perception on benefits of e-learning

\begin{tabular}{|l|c|c|c|c|c|c|}
\hline & $\begin{array}{c}\text { Males } \\
\boldsymbol{\%}^{-}\end{array}$ & $\begin{array}{c}\text { No of } \\
\text { males }\end{array}$ & $\begin{array}{c}\text { Females } \\
\text { \% }\end{array}$ & No of females & $\begin{array}{c}\text { Total } \\
\text { \% }\end{array}$ & $\begin{array}{c}\text { Total } \\
\text { No=150 }\end{array}$ \\
\hline 1. Would you find it useful- Yes & 100 & 72 & 96 & 75 & 98 & 147 \\
\hline -No & 0 & 0 & 4 & 3 & 2 & 3 \\
\hline $\begin{array}{l}\text { 2. Would you be motivated to use it- } \\
\text { Yes }\end{array}$ & 86 & 62 & 94 & 73 & 90 & 135 \\
\hline -No & 14 & 10 & 6 & 5 & 10 & 15 \\
\hline $\begin{array}{l}\text { 3.E -learning is beneficial as it is an } \\
\text { interactive mode - Agree }\end{array}$ & 81 & 58 & 88 & 69 & 84.5 & 127 \\
\hline -Neutral & 0 & 0 & 2 & 1 & 1 & 1 \\
\hline -Disagree & 19 & 14 & 10 & 8 & 14.5 & 22 \\
\hline $\begin{array}{l}\text { 4.E-learning is useful as courses are } \\
\text { readily available online }\end{array}$ & 81 & 58 & 83 & 65 & 82 & 123 \\
\hline - Agree & 18 & 13 & 13 & 10 & 15.5 & 23 \\
\hline -Neutral & 1 & 1 & 4 & 3 & 2.5 & 4 \\
\hline -Disagree & 74 & 53 & 83 & 65 & 78.5 & 118 \\
\hline $\begin{array}{l}\text { 5.E-learning is cost effective } \\
\text { - Agree }\end{array}$ & 24 & 17 & 33 & 6 & 28.5 & 43 \\
\hline - Disagree & & & & & \\
\hline
\end{tabular}




\begin{tabular}{|c|c|c|c|c|c|c|}
\hline \multirow{2}{*}{$\begin{array}{l}\text { If you disagree, then why } \\
\text { - Neutral }\end{array}$} & \multicolumn{6}{|c|}{$\begin{array}{l}\text { Charges to be incurred for the use of services and if services are not proper, } \\
\text { further change of service provider may be required which can incur further } \\
\text { charges. }\end{array}$} \\
\hline & 2.7 & 2 & 1.2 & 1 & 2 & 3 \\
\hline $\begin{array}{l}\text { 6. Implementing e-learning would } \\
\text { improve performance - Yes }\end{array}$ & 99 & 71 & 99 & 77 & 99 & 148 \\
\hline$-\mathrm{No}$ & 1 & 1 & 1 & 1 & 1 & 2 \\
\hline $\begin{array}{l}\text { 7.E-learning enabled training would } \\
\text { help in better understanding of the } \\
\text { course than formal teaching } \\
\text { methods } \\
\text {-Agree }\end{array}$ & 74 & 53 & 53 & 41 & 63.5 & 94 \\
\hline - Neutral & 6 & 4 & 5 & 4 & 5.5 & 8 \\
\hline -Disagree & 21 & 15 & 42 & 33 & 31.5 & 48 \\
\hline $\begin{array}{l}\text { 8. E-learning would help to learn on } \\
\text { your own at your own pace } \\
\text { - Agree }\end{array}$ & 55.5 & 40 & 54 & 42 & 54.6 & 82 \\
\hline - Neutral & 4 & 3 & 5 & 4 & 4.4 & 7 \\
\hline - Disagree & 37.5 & 27 & 41 & 32 & 39 & 59 \\
\hline $\begin{array}{l}\text { Thus from Table 2, it is observec } \\
\text { eed that e-learning was beneficial } \\
\text { eractive session and courses are } \\
\text { ine. } 78.5 \% \text { [118] students think i }\end{array}$ & & & $\begin{array}{l}\text { ecti } \\
\text { Wo } \\
\text { than } \\
\text { arn } \\
\text { in p }\end{array}$ & $\begin{array}{l}33.5 c \\
0 \text { in } \\
\text { teach }\end{array}$ & $\begin{array}{l}\text { eel th } \\
\text { under } \\
\text { hods. }\end{array}$ & $\begin{array}{l}\mathrm{b} \text { enabl } \\
\text { ag of } \\
6 \text { [82] } \mathrm{f} \\
\text { our own }\end{array}$ \\
\hline
\end{tabular}

Table 3: Students perception about challenges of e-learning

\begin{tabular}{|c|c|c|c|c|c|c|}
\hline & $\underset{\%}{\text { Males }}$ & $\begin{array}{l}\text { No of } \\
\text { males }\end{array}$ & $\begin{array}{c}\text { Females } \\
\%\end{array}$ & $\begin{array}{c}\text { No of } \\
\text { females }\end{array}$ & $\begin{array}{c}\text { Total } \\
\%\end{array}$ & $\begin{array}{c}\text { Total } \\
\text { No=150 }\end{array}$ \\
\hline $\begin{array}{l}\text { 1. Availability of ready access to e- } \\
\text { learning courses - Yes }\end{array}$ & 73 & 53 & 75.6 & 59 & 74.6 & 112 \\
\hline$-\mathrm{No}$ & 26.3 & 19 & 37.2 & 29 & 32 & 48 \\
\hline If no, then why & \multicolumn{6}{|c|}{ Lack of constant net connection, charges for the services } \\
\hline $\begin{array}{l}\text { 2. Its disadvantages as it would replace } \\
\text { faculties } \\
\text { - Agree }\end{array}$ & 38 & 27 & 38 & 30 & 38 & 57 \\
\hline If agree, why & \multicolumn{6}{|c|}{ At ease with traditional teaching, can interact in person the faculties. } \\
\hline - Neutral & 35 & 25 & 37 & 29 & 36 & 54 \\
\hline - Disagree & 28 & 20 & 24 & 19 & 26 & 39 \\
\hline $\begin{array}{l}\text { 3. It would make students to skip } \\
\text { traditional classes- Yes }\end{array}$ & 58 & 42 & 64 & 50 & 61 & 92 \\
\hline$-\mathrm{No}$ & 42 & 30 & 36 & 28 & 39 & 58 \\
\hline 4. Distracted on using e-learning-Yes & 39 & 28 & 35 & 27 & 37 & 55 \\
\hline If yes, then why & \multicolumn{6}{|c|}{$\begin{array}{l}\text { Singled out, no monitoring, no friends around or if present, constant } \\
\text { interaction would be there }\end{array}$} \\
\hline$-\mathrm{No}$ & 61 & 44 & 65 & 51 & 63 & 95 \\
\hline $\begin{array}{l}\text { 5. Adapting difficulties } \\
\text { On implementing newer e-learning } \\
\text { modules and tools. - Yes }\end{array}$ & 14 & 10 & 5 & 4 & 9.5 & 14 \\
\hline -No & 86 & 62 & 92 & 72 & 89 & 134 \\
\hline
\end{tabular}

Thus from Table 3, it is observed that 32\% [48] fear the challenge of ready access to the e-learning courses. 38\% fear that e-learning can replace faculties which was a disadvantage to those students who prefer the traditional teaching method and $37 \%$ of the students feels that they would be distracted while using such high end technologies as a check on them will not be there. Though 98\% have not adapting difficulties, yet 9.5\% claim that they can have challenges.

Suggestions/Comments: Few students expressed that there should be a platform where educative videos and important case based presentations be shared. Learning course materials should be an interactive session with the faculties. Online discussions and online work submissions should also be incorporated. 
Implementation, both at Institutional and university level should also be done. These facilities should be for free or for a very nominal cost. Yet, some mentioned that they would prefer the traditional teaching method as they felt that they will get bored in a virtual environment, they are not at ease with use of technology and their studies may get hampered due to interrupted internet connection.

\section{Discussion}

In the current scenario, for training tomorrow's physician where dynamic changes are evolving in health care delivery system with new advancements, humongous challenges needs to be shouldered by current academicians with respect to decreased teaching time and appropriately training the learners, than their predecessors. Finding time to teach "new" fields such as genomics, palliative care, geriatrics, and complementary medicine is difficult when medical school curricula are already challenged to cover conventional materials. ${ }^{4}$ The conventional tutor centered training is now shifting from the learner centered model whereby the students are responsible of their own learning. Thus recent shift toward competency-based curricula emphasizes, the learning outcome and not the process of education. ${ }^{5}$

A positive trend is noted with many developed and developing countries adopting the Web-based, computer - based, Virtual Classrooms (VCR), and digital collaboration teachings where the delivery of content is mostly via Internet, audio- and videotape, and CD-ROM. ${ }^{6}$ In our Institute, students do have access to internet in computer labs, but there are no well defined technological tools or a proper learning management systems [LMS] in place. This needs urgent attention, as a definite change is required in learning styles to keep pace with the developed scenario in learning mechanism.

The present study showed that the maximum [90\%] students are tech savvy and technology comprises an important part of their daily activities [Table 1]. As seen from the data, $85 \%$ students are aware about elearning and $92.5 \%$ want further guidance in e-learning, but the only resources available on site were computer labs, access to various online e-journal and educational websites, thus this necessitates the need for a proper well established e-learning platform like a Learning Management System [LMS] for students which will be in accordance with their learning needs and their curriculum too. This will serve as a supplement to the traditional teachings methods followed in the Institution and will thus enhance the students educational experiences. Almost 53.5\% [80]students used different forms of communications with faculties through emails, chats, blogs, face book, WhatsApps, instant messaging etc but it is observed that these tools are hardly integrated into the teaching and learning environment at the Institutional or University levels. This can be overcome by implementing LMS into the Institute which will definitely act as a bane for the learners due to its ready access of anytime and anywhere.

With regards to the benefits, it is observed from Table 2, that most agreed e-learning to be useful, especially as it was interactive and were motivated to use it for their educational intents. Thus bringing in proper interactive e-learning modules through LMS into curriculum would be worthy. $78.5 \%[118]$ agreed to it being cost effective and the ready availability of contents too. The doubt in 28.5\% [43] students over the cost effectiveness, might be due to the uncertainty over the expenditure that might incur for using the internet or whether a huge sum have to paid to the providers for using this facilities. But there are studies to show that elearning is cost effective, as it not only reduces travel cost especially in Palestine country where travel is very expensive due to the movement restrictions ${ }^{2}$ but with good infrastructure it would be easy to access too.

99\% agree that implementing e-learning would enhance their performance and some feel that web enabled training would help in better comprehension while for some $31.5 \%$ [48], traditional methods or a blend learning needs be considered. 39\% disagreed that e-learning can help them to learn at their own pace and time, but since they are exposed to only traditional learning methods, implementing a proper LMS can help them to learn at any place and any time.

With regards to challenges, the study showed, that $32 \%$ [48] think ready access is difficult [Table 3]. According to them there are network issues and the feasibility to use high end phone are not there. Also they are not sure if the infrastructure would allow them the ready access. 38\% agreed that with such technologies faculties could be replaced which they fear, as a problem can arise if a student prefers formal methods of training or a blended method of learning. Also more than 1/3rd [37\%] of the students feels that they would be distracted while using such high end technologies as it is not in a controlled environment. Peers may disturb by talking, walking, sleeping when the topic is being discussed online, can be monotonous, but for sure, 89\%[134] students agreed that they would not any difficulties in adapting to these newer learning e-modules or tools.

Many studies have procured data with regards to the benefits, challenges and effectiveness of e-learning in regards to various learning styles as well as various learning management systems.

Katherine Schilling et al's ${ }^{7}$ study was on the design and effectiveness of an interactive, Web-based curriculum on Evidence Based Medicine[EBM] in family medicine. 238 Students were subjected to traditional clerkship experience, of which 134 received additional training via an on-line curriculum that included learning modules in MEDLINE searching skills and EBM skills, while 104 acted as control. The results of the study demonstrated that e-learning 
resulted in higher-quality literature search strategies, identification of higher-quality evidence, and improved confidence in information retrieval and analysis skills. With current study participants showing confidence that e-learning can better their performance, it would be appropriate to introduce e-learning module or tools via a learning management platform so as to stream line their learning environments.

In Warnecke E et al study, ${ }^{8} 67$ medical students were exposed to e-learning packages which included audio - visual lecture, theory outlines, students as well as doctor's consulting patient videos and feedback process videos, while Tiago Taveira-Gomes et $\mathrm{al}^{9}$ developed a study platform named alert student, which included Flashcards, Notebooks, Study Groups, Quiz modes, as a free web application to assess the usability of an adaptive computer supported collaborative learning system for medical students. Both the studies showed that students perceived these platform/ packages to be effective in increasing their study performance and were willing to use it as a reference tool for study management. Benefits included participants' confidence, style and structure of consulting skills which were documented. With such strong positive feedback from these studies and with $82-85 \%$ students of the current study agreeing that readily available courses with interactive sessions would be beneficial, it is proposed that the Institute should inculcate e-learning platforms like the LMS for their benefit.

The study done by Aboshady $\mathrm{O}$ et $\mathrm{al}^{10}$ assessed the prevalence of awareness and use of massive open online courses (MOOCs) among 2106 medical undergraduates in Egypt, along with its limitations and satisfaction of using it through a questionnaire. 21.7\%[456] knew the term MOOCs. Out of these, $29.8 \%$ students had enrolled in at least one course, but only $18.4 \%$ had courses completion certificates and the failure of completion included slow Internet speed (73; $53.7 \%$ ) and lack of time. Amongst completed course students, less satisfaction regarding student-instructor $(8 ; 32 \%)$ and student-student $(5 ; 20 \%)$ interactions was noted. As $85 \%$ students of the current study are aware about e-learning, challenges with regards to time and speed can be dealt with a well designed LMS in place and a good infrastructure.

Even Han H's study ${ }^{11}$ investigated medical students' hardware and software use; perception of educational technology (ET) and its use along with online behaviours. 120-item survey was conducted on 123 medical students at the Southern Illinois University School of Medicine. Students perceived most of educational tools and technologies and LMS useful for their learning. Some considered social networking tools less useful, despite their frequent use while some were less satisfied with technology integration in the curriculum. A study conducted by ALFRED et al ${ }^{12}$ also, assessed the effectiveness of the use of a competitive learning tool on the academic achievement and satisfaction where 285 human immunology students were divided into experimental and control group and subjected to pretest - posttest design. The students using tools had better academic performance, were motivated, fostered cooperation among students and felt it provided a pleasant classroom environment. Thus in our Institution, the need for a well established LMS and its proper incorporation into the curriculum can mold the students to be more focused, as $98 \%$ feel it will be useful and improve their performance by creating a better learning environment.

Chandrasekar et al's ${ }^{13}$ study had data of 180 medical students of using ICT in their learning process and had assessed their knowledge and perceptions of the possible effect of ICT application, in the subject of Surgery. Most students were confident with computer usage and its applications and visited various educative sites, but the browsing information on those sites or the cited references were substandard. So as to bring about a good quality literature search, for those generating level A evidences and practice, it is imperative that a well accepted LMS be monitored by trained educators with proper infrastructure be used at our Institution, as $90 \%$ are tech savvy, $89 \%$ claim to have no difficulties towards adaptation of such technologies and 99\% ascertain that such tools can better their performances.

The article by WIELSAW et $\mathrm{al}^{14}$ also presented data of e- learning efficiency by medical students at the Faculty of Health Sciences of the Medical University of Bialystok and the results of the implementation of an electronic examination at the Faculty of Medicine, Department of Pathophysiology. Benefits noted were that learning materials available were prepared on a high level of advancement in terms of content and methodology, availability of non-stop e-learning portal facilitated good preparation for final exam and helped them acquire and master their knowledge in the given field. Solimann MM et al's ${ }^{15}$ study which was conducted at the College of Medicine at King Saud University (KSU) had reformed its curriculum in 2009 from a traditional to a system-oriented hybrid curriculum. The objective of the study was to determine the perception of the second batch (reformed curriculum) of medical graduates about the educational environment using DREEM Inventory and it was noted that the general perceptions of the students in all five sub-scales were positive and the overall student's perception about the educational environment was satisfactory too. 63.5 performance $\%$ respondents in the current study were positive that an e-learning enabled training would enhance their and thus by introducing a LMS designed to students' curricular needs in our Institution, will definitely aid their learning process while $31.5 \%$ who disagreed to such tools, once exposed and trained in using LMS, can reap its benefits.

Briz-Ponce el $\mathrm{al}^{16}$ study looked into different behavior patterns based on experiences that influence 
medical students of Coimbra University into mobile usage for learning. A strong attitude towards mobile use for learning (57\%) and willingness to recommend it (40.5\%) was noted. Social Influence $(31.9 \%)$ was a factor too towards the Attitude and Behavioral Intention of using Mobile Learning. The same was noticed by Guttmann $\mathbf{J}$ et al ${ }^{17}$ who systematically analyzed the use of digital and non-digital learning resources by 338 medical students and a high prevalence and acceptance of digital learning resources, in particular mobile applications was noted. As the current study students are $90 \%$ tech savvy, further implementation of a well established LMS which can also be accessed by mobile, can lead to further effective learning.

Some students of the current study had expressed in comments/suggestions that access to learning course material should be an interactive session with faculties. There should be a platform where educative videos and important case based presentations can be shared. Online discussions and online work submissions should also be incorporated. They requested that a proper implementation, both at Institutional and university level should also be done. It was noted that graduation rates for 10 generations of 8 Dutch medical schools between 1989 and 1998, showed that students using active-learning curricula, graduated on average $8 \%$ more/year and on average 5 months earlier too. ${ }^{18}$ Thus to see a positive change, the need for a proper implementation of a learning management system is required along with training sessions for students thereby improving their performances. This may also reduce resistance to change, enhance students' satisfaction, and ultimately improve the learning experience. ${ }^{19}$

The present students have further expressed that such facilities should be provided for free or for a very nominal cost. Yet, there are some who suggest that they would prefer the traditional method too as they can get bored in a virtual environment as well as no ease with use of technology and difficulties with its language too. The hardships associated with the terminologies used in ICT were also expressed by Elango et al too. ${ }^{20}$ The disinterest to use web based learning materials/ resources were also expressed by Edirippulige $\mathrm{S}$ et al. ${ }^{21}$ Thus, to get the positive desired results, both learners and teachers need to adopt a new attitude towards such e-learning models ${ }^{22}$ and with integration of e-learning in curriculum, educators have to become more involved as facilitators of learning and assessors of competency. ${ }^{23}$

Thus from all the above mentioned studies, ${ }^{7-21}$ it is noticed that there are more advantages than disadvantages, of using e-learning tools and technologies and it was also found to be useful and effective to teaching learning process and hence incorporating a well designed LMS in our Institution can add much more value to the learning process as it can accommodate the various suggestions and comments. ${ }^{24-26}$

A further extended study can be obtained by incorporating proper e-learning modules along with a well managed LMS and good infrastructure. Further information can be obtained as to why majority are eager to adapt earlier while some of them trail down, some improve and yet some are stagnant in training. The study should also be conducted for a longer periods in phases to see the after effects of introducing virtual learning strategies. It can also be evaluated at various stages so as to explore the changes in the learning experiences of the students. Data of student experiences on usage various tools other than just the learning materials such as discussions, submissions and assessments, can also be procured.

\section{Conclusion}

The students do find e-learning to be useful and beneficial in increasing their performances. Thus elearning should be further utilized in a blended learning environment to support face-to-face teaching and allow for flexibility in delivery of medical education. The results obtained from this study shows the need of implementing a properly designed LMS which should be designed according to the learning curricular needs of the students thereby reaping the potential benefits of e-learning tools and further stimulating and motivating them for its increased use and a better teaching learning experience.

\section{References}

1. Dobre I. Evaluation of Students Knowledge - An Experiment in E-Learning. 2007;LIX(2):43-8.

2. Shraim K, Khlaif Z. Students' readiness towards elearning. A case study of virtual classrooms for secondary education in Palestine. 3rd Annu Forum elearning [Internet]. 2010;1-11. Available from: http://elexforum.hbmeu.ac.ae/Proceeding/PDF/Student $s$ Readiness for e-Learning.pdf

3. Ahmed HMS. Hybrid E-Learning Acceptance Model: Learner Perceptions. Decis Sci J Innov Educ. 2010;8(2):313-46.

4. Ozuah PO. Undergraduate medical education: thoughts on future challenges. BMC Med Educ. 2002 Jul 30 [cited 2018 Jun 29];2:8. Available from: http://www.ncbi.nlm.nih.gov/pubmed/12149136

5. Leung W-C. Competency based medical training: review. BMJ. 2002;325(7366):693-6.

6. Kaplan-Leiserson E. E-Learning Glossary [Internet]. 2002 [cited 2018 Jul 5]. Available from: https://www.puw.pl/sites/default/files/content_files/zas ob_do_pobrania/355/elearn-gloss-learncircuits.pdf

7. Schilling K, Wiecha J, Polineni D, Khalil S. An interactive web-based curriculum on evidence-based medicine: design and effectiveness. Fam Med. 2006;38(2):126-32.

8. Warnecke E, Pearson S. Medical students' perceptions of using e-learning to enhance the acquisition of consulting skills. Australas Med J. [Internet]. 2011;4(6):300-7.

9. Taveira-Gomes T, Saffarzadeh A, Severo M, 
Guimarães MJ, Ferreira MA. A novel collaborative elearning platform for medical students - ALERT STUDENT. BMC Med Educ. [Internet]. 2014;14(1):143.

10. Aboshady OA, Radwan AE, Eltaweel AR, Azzam A, Aboelnaga AA, Hashem HA, et al. Perception and use of massive open online courses among medical students in a developing country: Multicentre crosssectional study. BMJ. Open [Internet]. 2015;5(1):e006804. Available from: http://www.ncbi.nlm.nih.gov/pubmed/25564149

11. Han H, Nelson E, Wetter N. Medical students' online learning technology needs. Clin Teach. 2014;11(1):159. Available from: http://www.ncbi.nlm.nih.gov/pubmed/24405913

12. Corell A, Regueras LM, Verdú E, Verdú MJ, de Castro JP. Effects of competitive learning tools on medical students: A case study. Ito E, editor. PLoS One. 2018;13(3):e0194096. Available from: http://dx.plos.org/10.1371/journal.pone.0194096

13. Mahakalkar C, El A. Students' Perception of the Effectiveness of ICT use in Improving Teaching and Learning in Surgery. JHSE. 2013;1(1):17-24.

Available from: http://www.academia.edu/15192210/Students_Percepti on_of_the_Effectiveness_of_ICT_use_in_Improving Teaching_and_Learning_in_Surgery

14. W. Półjanowicz, M. Roszak, B. Kołodziejczak AB. An analysis of the effectiveness and quality of e-learning in medical education. 2014 [cited $2018 \mathrm{Jul}$ 14];(October). Available from: https://depot.ceon.pl/bitstream/handle/123456789/1178 9/13_AN ANALYSIS OF THE EFFECTIVENESS.pdf?sequence $=1$

15. Soliman M, Sattar K, Alnassar S, Alsaif F, AlSwat K, Alghonaim M, et al. Medical students\&rsquo; perception of the learning environment at King Saud University Medical College, Saudi Arabia, using DREEM Inventory. Adv Med Educ Pract. 2017;8:2217. Available from: https://www.dovepress.com/medical-studentsrsquoperception-of-the-learning-environment-at-king-s-peerreviewed-article-AMEP

16. Briz-Ponce L, Pereira A, Carvalho L, Juanes-Méndez JA, García-Peñalvo FJ. Learning with mobile technologies - Students' behavior. Comput Human Behav. 2017;72:612-20. Available from: http://linkinghub.elsevier.com/retrieve/pii/S074756321 6303545

17. Gutmann J, Kühbeck F, Berberat PO, Fischer MR, Engelhardt S, Sarikas A. Use of Learning Media by Undergraduate Medical Students in Pharmacology: A Prospective Cohort Study. Vrana KE, editor. PLoS One. 2015;10(4): $\mathrm{e} 0122624$. Available from: http://dx.plos.org/10.1371/journal.pone.0122624

18. Schmidt HG, Cohen-Schotanus J, Arends LR. Impact of problem-based, active learning on graduation rates for 10 generations of Dutch medical students. Med Educ. 2009;43(3):211-8. Available from: http://www.ncbi.nlm.nih.gov/pubmed/19250347

19. Nicklen P, Keating JL, Maloney S. Exploring Student Preconceptions of Readiness for Remote-Online CaseBased Learning: A Case Study. JMIR Med Educ. 2016;2(1):e5. Available from: http://mededu.jmir.org/2016/1/e5/

20. Elango R, Gudep VK, Selvam M. Quality of eLearning: An Analysis Based on e-Learners' Perception of e-Learning. Electron J e-Learning.
2008;6(1):13. Available from:

http://issuu.com/academic-conferences.org/docs/ejelvolume6-issue 1-article58? mode=a_p

21. Edirippulige $S$, Marasinghe RB, Smith AC, Fujisawa Y, Herath WB, Jiffry MTM, et al. Evaluation of ELearning Practices in Undergraduate Medical Education: Results of a Survey in Sri Lanka. In: Gesellschaft für Informatik. 2007 [cited 2018 Jul 14]. p. 217. Available from: https://pdfs.semanticscholar.org/fb23/d8498cdcf8a5f08 ffcb044d72481012a73c9.pdf

22. Rozgiene I. Integrating ICT into Language Learning and Teaching [Internet]. [cited 2018 Jul 5]. Available from: http://www.academia.edu/2454849/Integrating_ICT_in to_Language_Learning_and_Teaching

23. Ruiz JG, Mintzer MJ, Leipzig RM. The impact of Elearning in medical education. Acad Med. 2006;81(3):207-12. Available from: http://www.ncbi.nlm.nih.gov/pubmed/16501260

24. Costa C, Alvelos H, Teixeira L. The Use of Moodle elearning Platform: A Study in a Portuguese University. Procedia Technol. 2012;5:334-43. Available from: https://www.sciencedirect.com/science/article/pii/S221 2017312004689

25. Oliveira PC de, Cunha CJC de A, Nakayama MK, Oliveira PC de, Cunha CJC de A, Nakayama MK. Learning Management Systems (LMS) and e-learning management: an integrative review and research agenda. J Inf Syst Technol Manag. 2016;13(2):157-80. Available from: http://www.jistem.fea.usp.br/index.php/jistem/article/v iew/10.4301\%25S1807-17752016000200001

26. Back DA, Behringer F, Haberstroh N, Ehlers JP, Sostmann K, Peters H. Learning management system and e-learning tools: An experience of medical students' usage and expectations. Int J Med Educ. 2016;7:267-73. Available from: http://www.ijme.net/archive/7/learning-managementsystem-and-e-learning-students-expectations/

How to cite this article: Mahajan $\mathrm{M} \mathrm{V}$, Kalpana. R. A study of students' perception about e-learning. Indian J Clin Anat Physiol. 2018;5(4):501-507. 